\title{
The Formation of a Technology-Based Fashion System, 1945-1990: The Sources of the Lost Competitiveness of Japanese Apparel Companies*
}

\author{
PIERRE-YVES DONZÉ \\ RIKA FUJIOKA
}

Over the past two decades, the Japanese apparel industry has lost its competitiveness after experiencing a period of fast growth from the postwar years to the early 1990s. In international literature in social sciences, most scholars offer ethnic-based explanations of fashion in Japan, stressing some specificities such as street fashion or star designers in Paris. This article, however, argues that such views are biased and cannot explain the current lack of competitiveness of the Japanese apparel industry. Using the concept of the "fashion system" and following a business history-oriented approach, we offer a new interpretation of the emergence of Western clothing and fashion in Japan during the second part of the twentieth century. This interpretation demonstrates that the characteristics of the Japanese fashion system lie in a focus on the issues of production and technology, both of which led both to an extreme segmentation of the domestic market and to weaker brands.

(C) The Author(s), 2020. This is an Open Access article, distributed under the terms of the Creative Commons Attribution licence (http://creativecommons.org/ licenses/by/4.0/), which permits unrestricted re-use, distribution, and reproduction in any medium, provided the original work is properly cited.

doi:10.1017/eso.2019.78

Published online March 19, 2020

*This work was supported by Murata Foundation (grant no. H30-30).

Pierre-Yves Donzé. Contact information: Osaka University, Graduate School of Economics, Machikaneyama 1-7, Toyonaka, Osaka, 560-0043, Japan. E-mail: donze@econ.osaka-u.ac.jp

RiKa FujIOKA. Kansai University, Faculty of Business and Commerce, 3-3-35 Yamatecho Suita-shi, Osaka, 564-8680 Japan. Email: fujioka@kansai-u.ac.jp 


\section{Introduction}

Although Japanese design and cultural goods have enjoyed an excellent reputation throughout the world since the end of the twentieth century, fashion has not benefited from that general trend. ${ }^{1}$ Except for Fast Retailing Co., the holding company of fast-fashion brand Uniqlo, the Japanese apparel industry presents a prominent lack of global competitiveness. According to the consultancy company Brand Finance, the 2017 global ranking of the top fifty most valuable fashion brands included only two from Japan (Uniqlo, in seventh, and Asics, in thirty-eighth). ${ }^{2}$ Even in their domestic market, Japanese fashion brands are weak. Interbrand's 2017 ranking of Japan's top forty most valuable domestic brands lists only one from the fashion industry (ABC-Mart, in thirty-third). ${ }^{3}$

Moreover, since the 1990s, the domestic Japanese market has seen Japanese apparel companies facing growing competition from foreign brands that have invested massively in developing a dense network of stores, both in the luxury segment (Chanel, Dior, Prada, etc.) and in fast fashion (mostly H\&M and Zara). ${ }^{4}$ Finally, one must stress the decline of the size of the Japanese apparel market (from 15.3 trillion yen in 1991 to 10.5 trillion yen in 2013), a result of the country's aging population and a huge decrease in prices following deflation pressure and relocation of the production base to developing countries (import goods represented 36.1 percent of the domestic market in 1997 but 76.1 percent in 2013). ${ }^{5}$ Under these conditions, Japanese apparel companies face a serious concern: they must move into the global market but lack brands that are strong enough for that expansion. Hence, companies that used to be highly competitive in the domestic market lose their competitiveness when they go abroad. This is an intriguing feature that requires analysis.

Most of the works in Japanese by economists and other social scientists argue that the difficulties confronting Japanese fashion companies result from a shrinking domestic market, weak brand management, and late engagement in online sales. ${ }^{6}$ However, these explanations are rather descriptive; they note some facts that have led apparel companies to lose their competitiveness but do not explain why. Japanese researchers and

1. McGray, "Japan’s Gross National Cool”; Storz, "Innovation, institutions and entrepreneurs."

2. Brand Finance, Apparel 502017.

3. “Best Japan Brands 2017," accessed January 12, 2018, http://interbrand. com/newsroom/interbrand-japan-best-japan-brands-2017/.

4. Otani, Kim, and Takahashi, "International Presence and Fashion Business in Japan."

5. Apareru sapurai chen.

6. Meiji University, Za fasshon bijinesu; Ohara, Gurobarizeshon; Omura, Fasshon bijinesu no shinka; Sugihara and Somehara, Dare ga apareru wo korosu no ka. 
companies do not differentiate between the apparel industry and the fashion industry, either. As we will detail in the next section, the first is an industry that produces clothes, whereas the second produces cultural value and image. This misunderstanding has led scholars to neglect the cultural side and overestimate the issues of production and technology.

As for international literature on Japanese fashion, largely works in sociology and cultural studies, researchers offer scant clues for properly understanding the dynamics of the apparel industry. Most of the scholarship is dominated by the paradigm of the uniqueness of Japanese fashion, ${ }^{7}$ particularly an emphasis on the importance of street fashion. For example, Yuniya Kawamura maintains that "fashion is no longer controlled or guided by professionally trained designers but by the teens who have become the producers of fashion." ${ }^{8}$ During the 1980s and 1990s, some apparel companies and entrepreneurs, with the support of fashion magazines, took the opportunity to launch new brands and new styles that answered the demand for young customers. ${ }^{9}$ Since the 1990s, Japanese street fashion has even become an export, particularly to South Korea and the United States. ${ }^{10}$

A second feature of Japan would be what Kawamura calls "the structural weaknesses of fashion production."11 During the 1960s, Japan became an important market for Western fashion companies but only had the capability to produce domestic-oriented, culturally embedded fashion (street fashion). While the domestic apparel market was expanding, some Japanese orthodox designers moved to Europe, mainly to Paris, to pursue their careers; prominent examples include Kenzo Takada, Issey Miyake, Yoji Yamamoto, and Rei Kawakubo. ${ }^{12}$ This has become the prevailing explanation of how Japanese fashion has developed and why Tokyo was unable to establish itself as a global fashion capital after World War II. For example, sociologist Frédéric Godart argues that Tokyo was an important market and exerted a broad influence on global fashion through street fashion-but that most of its designers made their careers in Paris: "This absorption of Japanese talents by Paris has strengthened the position of the French capital at the expense of Tokyo, but has not emptied the Japanese capital of its creative energy, particularly with regard to street fashion."13

7. Jiratanatiteenun et al., "The Transformation of Japanese Street Fashion"; Kawamura, Fashioning Japanese Subcultures; Slade, Japanese Fashion; Steele, Japanese Fashion Now; Francks, The Japanese Consumer.

8. Kawamura, "Japanese Teens," 784.

9. Cameron, "Off-the-Rack Identities."

10. Azuma, "Pronto Moda."

11. Kawamura, “Japanese Teens,” 61.

12. Kawamura, "The Japanese Revolution in Paris Fashion”; Godoy, Style Deficit Disorder.

13. Godart, "The Power Structure of the Fashion Industry," 47. 
There are, however, major shortcomings in this model. Fashion in Japan is far from being limited to street fashion. There are hundreds of independent designers, a broad fashion-media industry, a handful of trade associations, various retailers, and numerous apparel companies active in Japan, but Kawamura and her followers do not take those elements into consideration. The problem with these approaches, then, is that they focus only on a small and specific part of fashion in Japan, one that cannot contribute to an understanding of the decline and lack of global competitiveness of the country's apparel industry. The ethnic approach toward Japanese clothing and fashion industry has led to misinterpretation.

A proper understanding of the declining Japanese apparel industry would benefit from insights in general works on competitiveness. The disappearing competitive advantage of Japanese manufacturing firms since the 1990s has attracted the attention of many scholars in management, international business, and business history. The management of technology approach provides a major model, arguing that a change in product architecture, characterized by the shift from the integral model to the module model, ${ }^{14}$ together with the implementation of global value chains and the reorganization of production networks in East Asia, ${ }^{15}$ explain this decline. Japanese manufacturing firms used to develop new products internally and were late to move to open innovation. ${ }^{16}$ Another set of explanations focuses on the lack of marketing capability and the difficulties that Japanese manufacturers have had in properly understanding customer needs throughout the world. ${ }^{17}$ Whereas these models contribute to an understanding of the decline of once globally competitive Japanese firms, they shed little light on the waning competitiveness of Japanese apparel companies.

The shift from a protected domestic market to the global market was the actual turning point in their decline, which means that attention should focus on this change. The industry study approach offers a valuable perspective for discussing the issues at hand. ${ }^{18}$ It argues that a proper understanding of the evolution of the conditions of competitiveness should not be limited to an analysis on the firm level but should concentrate on the specificities of the given industry. From that standpoint, comprehending the conditions of competition on the

14. Fujimoto, Nihon no monozukuri tetsugaku; Aoshima and Cusumano, Meido in japan ha owarunoka.

15. Shioji, Higashi ajia yui sangyo no kyosoryoku; Ozawa, The Rise of Asia; Kawakami and Sturgeon, The Dynamics of Local Learning in Global Value Chains.

16. Yonekura and Shimizu, Open inobeshon no manejimento.

17. Sato and Parry, "Formation of the New Japanese Style Management Strategy”; Endo, Delbridge, and Morris, “Does Japan Still Matter?”; Donzé and Borel, "Technological Innovation and Brand Management."

18. Bouwens, Donzé, and Kurosawa, Industries and Global Competition. 
domestic market—and examining why the shift toward the global market was so problematic-hinges on the defining characteristics of the Japanese apparel industry. This article argues that a major feature of the industry in question is the presence in Japan of a technology- and production-based fashion system, whereas the dominant model on the global market is a brand- and creation-based fashion system, as the following sections will detail. This difference results from the condition of the emergence of Western clothing in Japan after World War II. In his seminal work on the evolution of the post-World War II Japanese textile industry, Hiroyuki Itami demonstrated that the apparel companies in Japan emerged in close interaction with textile firms. ${ }^{19}$ This distinct historical development has resulted in a fashion system not directly linked to creative activities, a pattern common in the French and European perspective. As section 2 will explain, the manufacture of Western clothes was a new industry. Its emergence did not result from technological and regulatory change, as it might in most new industries, but rather from a change in demand conditions and cultural values. ${ }^{20}$

This article argues that a historical analysis and a business historyoriented approach are vital to a better understanding of the dynamics shaping the Japanese apparel industry. We focus here on the formative period of this industry: between 1945 and 1990. The main research questions we address are: Why do Japanese apparel companies not nurture strong brands? What are the causes of their lack of international competitiveness? How is fashion organized in Japan? To answer these questions, we apply the social science concept of the "fashion system" to the Japanese case.

\section{The Fashion System}

Since the 1960s, numerous scholars from a broad range of disciplines have considered fashion as a system, but very few have explored the question of what composes that system. In particular, many scholars in management, business history, and other social sciences use the term "fashion system" without defining it or even explaining how fashion can be understood as a system. ${ }^{21}$ Therefore, it is usually not used as an

19. Itami, Nihon no sen'i sangyo.

20. Gustafsson et al., "Emergence of Industries."

21. McCracken, "Who Is the Celebrity Endorser?"; Fontana and Miranda, "The Business of Fashion in the Nineteenth and Twentieth Centuries"; Jelinek, "Art as Strategic Branding Tool for Luxury Fashion Brands"; Skov, "Dreams of Small Nations in a Polycentric Fashion World”; Kapferer, “Abundant Rarity”; Steele, “Anti-fashion”; Godart, "The Power Structure of the Fashion Industry”; Segre Reinach, "China and 
analytical concept but as a mere synonym for "fashion business" or "fashion industry."

One of the very rare scholars to have discussed the concept of "fashion system" is sociologist Yuniya Kawamura. She argued that "fashion is a system of institutions, organizations, groups, producers, events and practices, all of which contribute to the making of fashion, which is different from dress and clothing." 22 Fashion is considered a cultural phenomenon supported by a system whose function is to legitimize creators and generate beliefs that hold fashion in regard. Business historian Regina Lee Blaszczyk used this idea of "fashion system" to emphasize the broad range of actors in the industry, particularly what she calls "intermediaries" between producers and consumers. However, neither Kawamura nor Blaszczyk explained the function of such a system from a perspective of business and profitability of firms. ${ }^{23}$ Because fashion is a business, its organization as a system should also be discussed from this perspective.

Literature in management, political economy, and business history has broadly discussed the organization of business as a system, but not without contradictions and lack of clarity. Business has been considered a system at various levels. First, at the firm level, management scholars and consulting firms like McKinsey developed "business systems" (some of them also using the term "business models") as tools for improving the management of companies. They comprise a set of actions and behaviors that managers should follow to conduct their company business successfully. ${ }^{24}$ Second, in the context of research on varieties of capitalism, many scholars have argued that there were various national business systems around the world. ${ }^{25}$ From this perspective, business systems consist of an ensemble of actors (firms, government, labor unions, etc.) and institutions (interfirm transactions, financial system, labor market, welfare, etc.) whose interactions differ between countries. Third, business systems can be observed at the level of industry and describe the nature of interfirm relations. For example, supply chains in the car industry, ${ }^{26}$ commodity business by Japanese

Italy”; Kawamura, “Japanese Teens”; Rabellotti, "How Globalisation Affects Italian Industrial Districts.”

22. Kawamura, Fashion-ology, 43.

23. Blaszczyk, The Color Revolution; Blaszczyk and Wubs, The Fashion Forecasters; Blaszczyk and Pouillard, European Fashion.

24. Gluck, "Strategic Choices and Research Allocation”; Bales et al., "The Business System."

25. Whitley, "Internationalization and Varieties of Capitalism"; Witt and Redding, The Oxford Handbook of Asian Business Systems; Lundvall, "National Business Systems and National Systems of Innovation."

26. Shimokawa, “Japan’s Keiretsu System”; Donnelly and Morris, "Structural Change in the Chinese Car Industry." 
general trading companies, ${ }^{27}$ or global value chains in the electronics industry ${ }^{28}$ can be considered business systems. The main objective of such systems is to support the sustainability (stability and profitability) of enterprises that engage in them. Here, we use the business system approach from this third perspective. Fashion can indeed be considered a business system that includes a broad range of enterprises whose interactions ensure their sustainability.

Few scholars working on Western cases have conducted research on fashion as business systems that include designers, textile producers, retailers, and promoters. The organization science approach made it possible to emphasize the existence of slightly different models in France, Italy, and the United States. ${ }^{29}$ The formation of the Italian fashion system has been a particular subject of study by business historians. Ivan Paris argued that the successful development of fashion in Italy during the 1960s relied not only on the presence of haute couture and creativity but especially on the interactions between companies engaged in textile, garment, leather goods, and accessories. ${ }^{30}$ He thus maintains that the fashion system "combines vertical integration of sectors comparable in terms of production processes and horizontal integration of sectors that produce different kinds of goods." ${ }^{\text {"11 }}$ The most important role of this system is to reduce what he calls the "fashion risk," ${ }^{32}$ that is, a change in the tastes and needs of consumers. Cooperation between various actors within the Italian fashion system made it possible to offer a broad range of products and overcome this risk. As for Elisabetta Merlo, she has pursued this perspective with a study of cooperation between the largest textile company in Italia (Gruppo Finanziario Tessile) and fashion designer Biki to highlight that the proximity between two different kinds of enterprises supported the expansion of Italian fashion. ${ }^{33}$

However, as we will demonstrate in this article, the function of fashion systems in the context of business systems is not simply to increase the flexibility of product development but also to ensure and increase the profitability of companies engaged in the system. The French fashion system is a case in point. During the first part of the twentieth century, most Paris-based haute couture companies suffered

27. Tanaka, "The Changing Business Models of Postwar Japan’s Sōgō Shōsha."

28. Mudambi and Puck, "A Global Value Chain Analysis"; Wei et al., "Corporate Networks, Value Chains, and Spatial Organization."

29. Djelic and Ainamo, "The Coevolution of New Organizational Forms in the Fashion Industry."

30. Paris, "Fashion as a System."

31. Ibid., 528.

32. Ibid., 552.

33. Merlo, "When Fashion Met Industry." 
from low profitability due to their small size and narrow business model (high-quality handmade goods for a wealthy elite). ${ }^{34}$ After World War II, and especially since the 1960s, haute couture companies started cooperating with other firms (perfume makers, retailers, confection companies, media companies, etc.) to build a sustainable model based on investing in brand making through haute couture creation and increasing profits through the sales of accessories and ready-to-wear items. ${ }^{35}$ French semiologist Roland Barthes was one of the first to emphasize, during the 1960s, that media had a major influence on fashion and fashion consumption, although he did not discuss it from a perspective of business. ${ }^{36}$ His work was later the basis for work by sociologist Yuniya Kawamura, who stressed the importance of institutions as intermediaries between producers and consumers in the fashion business. ${ }^{37}$ Trade associations, the mass media, and events legitimize producers through various actions and consequently contribute to creating fashion as a cultural consumer good. ${ }^{38}$

Figure 1 illustrates the fashion system in Western countries and its main elements (apparel manufacturers, designers, media, retailers, trade associations, fashion shows, and celebrities). The activities of these various actors, as well as their interactions, contribute to the production of fashion as a cultural value, the profitability of enterprises, and the sustainability of the overall business system. Apparel manufacturers make clothes but not fashion. They need the support of other actors that contribute to legitimize their designers, brands, and products as "fashion." 39 For example, trade associations organize fairs and events during which apparel companies and designers meet and discuss topics like new color trends. ${ }^{40}$ Retailers, be they department stores, shopping centers, or monobrand stores, offer a space to advertise products and have a deep impact on the construction of brand identity. ${ }^{41}$ Fashion shows, usually organized by trade associations, are major events that give designers and apparel companies opportunities to communicate with consumers through fashion media. ${ }^{42}$ Hence, a focus on the fashion system, rather than only on

34. Brachet Champsaur, "Madeleine Vionnet and Galeries Lafayette"; Grumbach, History of International Fashion, 86-104.

35. Okawa, "Licensing Practices at Maison Christian Dior"; Donzé and Wubs, "Storytelling and the Making of a Global Luxury Fashion Brand."

36. Barthes, The Fashion System.

37. Kawamura, Fashion-ology.

38. McCracken, "Culture and Consumption."

39. Dion, "Légitimité et légitimation des marques."

40. Blaszczyk and Wubs, The Fashion Forecasters.

41. Birtwistle and Moore, "Fashion Clothing-Where Does It All End Up?"

42. Bartlett, Cole, and Rocamora, Fashion Media. 


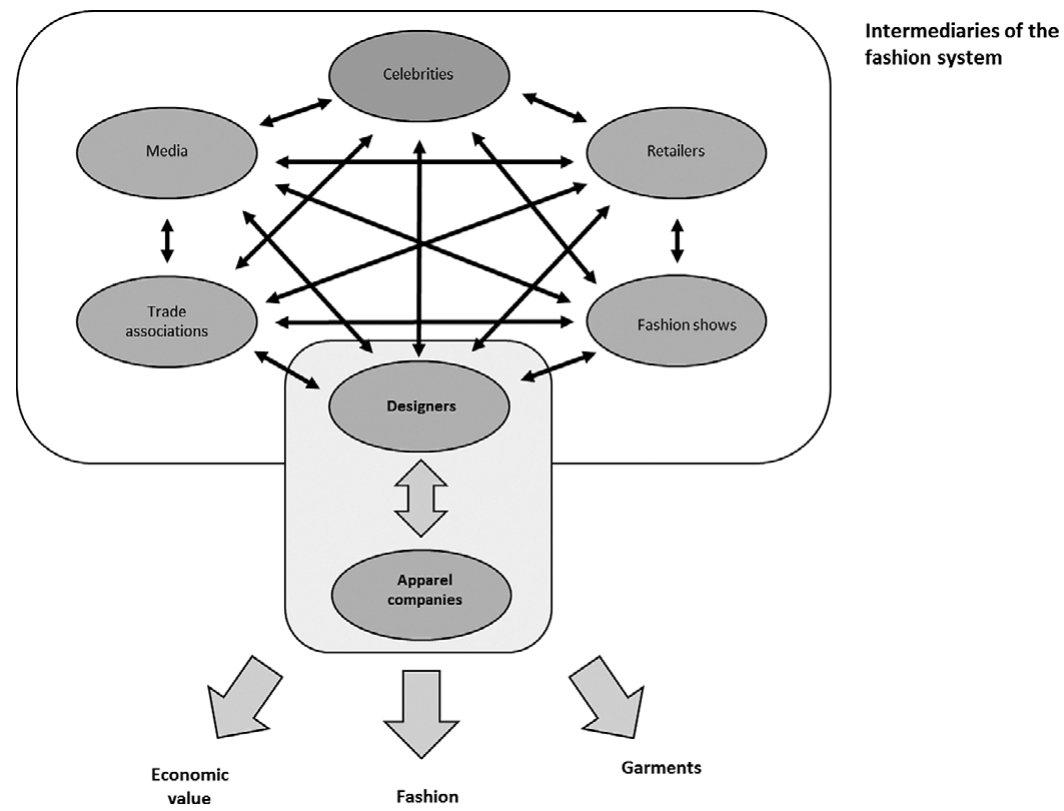

Figure 1 Organization of the Western fashion system.

Source: Designed by the authors.

apparel manufacturers, is essential to a proper understanding of the industry in question.

In the following sections, we analyze the emergence and development of this system in Japan between the end of World War II and the early 1990s. In particular, we focus on the interactions between the different elements of the Japanese fashion system and apparel companies in order to understand the specificity of how the interactions evolved. This article is comprised of three main sections. Section 2 discusses the development of the apparel industry itself after World War II, within the context of the westernization of consumption and the shift from Japanese to Western clothes. Section 3 focuses on the fashion system and its main actors. Section 4 goes back to apparel companies and analyzes their fashion strategies in relation to the findings from Section 3. Finally, the conclusion discusses the outcomes of this article and addresses research questions.

\section{Making Western Clothes in Japan}

The development of the Western clothing industry in Japan followed a path totally different from its counterparts in Europe and the United States. Western fashion saw a sudden, massive introduction into 
Japanese society and dramatically transformed traditional kimono fashion after World War II. In order to fully understand the formation of the Japanese fashion system, it is important to examine first the birth and growth of Western-style clothing companies in Japan alongside the development of department stores. This section covers how the Western clothing industry developed in Japan.

\section{The Development of Clothing Companies}

Historically, the Japanese apparel industry has been led by large spinning manufacturers that engaged as early as the last decades of the nineteenth century in the mastering of technology for mass production. This is one of the reasons for the emergence of an apparel industry based on production and technology. ${ }^{43}$ The Japanese cotton-spinning industry was very competitive during the interwar period; Japan became the world's largest cotton-fabric exporter by 1933, and exports of cotton products, mainly fabrics, were Japan's largest export in $1934 .{ }^{44}$ In the 1930s, an apparel industry, still essentially producing fabric for kimonos on the domestic market, took shape with three main types of businesses: large cotton-spinning manufacturers; small, highly interdependent companies that focused on a particular manufacturing process (e.g., dying, weaving, or finishing); and wholesalers, which linked the spinning manufacturers, small manufacturers, and retailers. Even after World War II, Japan's quantities of textile exports once again became the world's largest in 1951. However, the Japanese cottontextile industry gradually declined during the period of high economic growth between 1954 and 1973, while the heavy and chemical industries, along with the electronics industry, developed considerably. The output levels and subsequently the volume of textile exports decreased after the trade conflict with the United States around $1970 .^{45}$

In contrast with large spinning manufacturers, weaving and clothing manufacturers were relatively small, as were wholesalers and retailers. For example, companies with fewer than five employees formed 45.7 percent of all clothing wholesalers in 1970 and 42.9 percent in 1976. Among retailers, that same rate was almost 80 percent in 1960 and about 75 percent in $1972 .{ }^{46}$ Around 84 percent of all textile companies, meanwhile, had fewer than ten employees in 1965-and there was only one company with over one thousand employees; the textile sector then developed a strong tendency to include high proportions of small-scale companies: for instance, the percentage of textile companies with fewer

\footnotetext{
43. Choi, "The Genesis of Modern Management of Technology."

44. Abe and Hirano, Seni Sangyo, 71.

45. Ibid., 81.

46. Census of Commerce, 1960, 1970, 1972, 1976.
} 


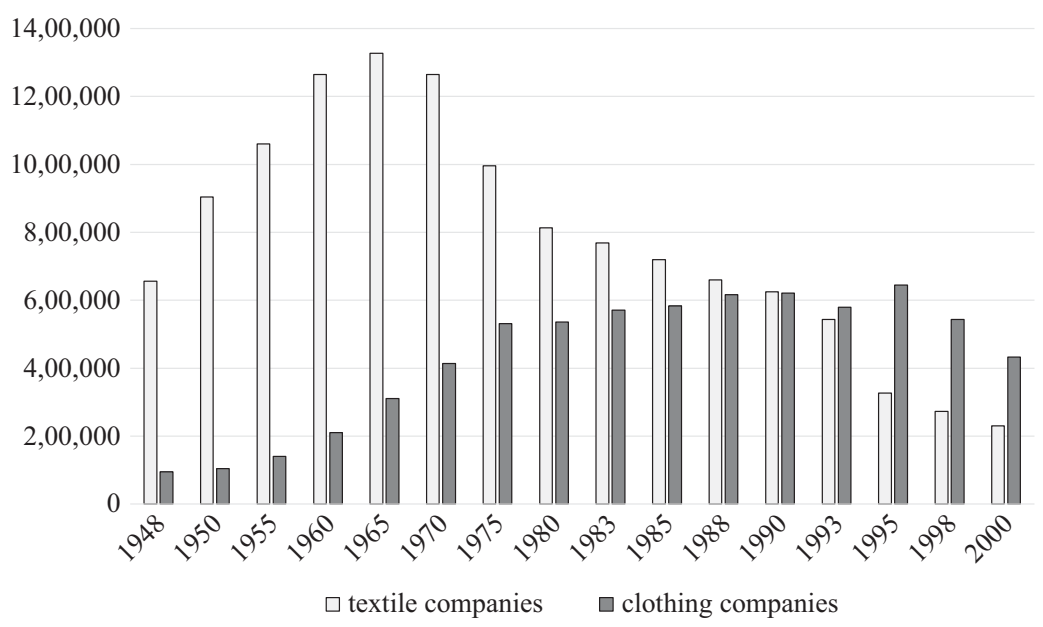

Figure 2 Number of employees of all textile and clothing companies in Japan, 1948-2000.

Note: Data not available before 1948.

Source: Census of Manufacture (MITI).

than ten employees was 89 percent in 1970, 92 percent in 1975, and 93 percent in $1980 .{ }^{47}$ Concentrated in clusters, these small-scale companies were flexible and able to respond to rapidly changing fashion trends, unlike spinning manufacturers. ${ }^{48}$

Yet the major feature of the Japanese textile industry during the decades following World War II was the growing importance of apparel makers and the decline of other manufacturers. Figure 2 perfectly captures the shift in balance between the textile industry and apparel industry. The number of employees of all textile companies, including those in silk reeling, spinning, twisting, weaving, knitting, dyeing, and printing, consistently declined in the second half of the twentieth century, dropping especially steeply from more than one million employees in 1965 and 1970 to 624,000 in 1990 and fewer than 230,000 in 2000. The number of employees per clothing company, on the other hand, increased consistently through the early 1990s, growing from 310,000 employees in 1965 to a peak of 644,000 in 1995. Total employment in clothing overcame employment in textiles in 1993.

The growth of the apparel sector resulted from the fast-increasing popularity of Western fashion in Japan, along with the high economic growth and industrial development of the late 1950s and early 1960 s. Figure 3 shows that Western-style clothes were the driving force for the

47. Census of Manufacture, 1965, 1970, 1975, 1980.

48. Ota, Seni Sangyo no Seisui to Sanchi Chusho Kigyo. 


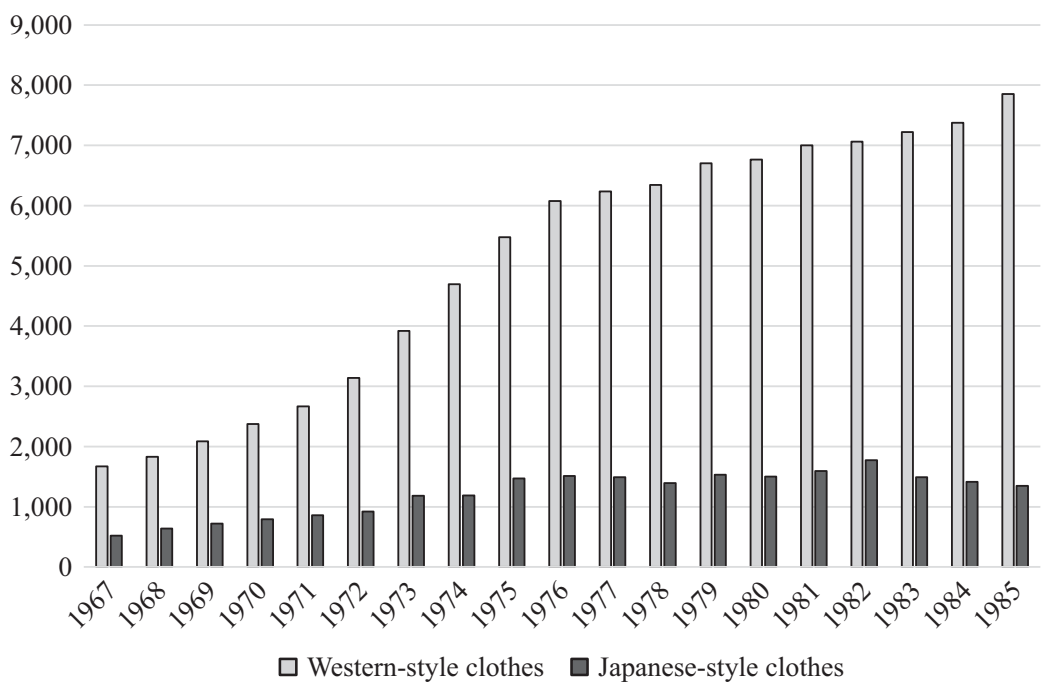

Figure 3 Annual averages of monthly workers' household expenses on clothes.

Note: Data unavailable before 1967.

Source: Household Expenditure Survey.

consumption of garments in Japan from the second half of the 1960s to the mid-1980s. In 1967, they already represented 76.3 percent of workers' expenses for clothes, which means that Japanese-style items had become a minority part of the larger fashion arena. The share of Western-style clothes expanded gradually during the following years, reaching 81.8 percent in 1980 and 85.4 percent in 1985. Between 1967 and 1985, spending on Western-style clothes multiplied by 4.7-as opposed to 2.6 times for Japanese-style clothes.

Western garments were first introduced in the form of tailor-made clothes for the upper and upper-middle classes, whereas mass-market consumers began making their own Western-style clothes at home, shifting gradually to acquisition on the market. This new demand represented a huge business opportunity for numerous entrepreneurs. Consequently, the number of apparel companies and wholesalers increased dramatically. For example, in 1966, there were 5,858 women's clothing manufacturers; that number increased to 10,254 in 1972 and 14,204 in 1976-more than doubling (2.5 times) over ten years. Women's clothing wholesalers exhibited a similar trend. From 1966 to 1976, the number of women's clothing wholesalers rose 1.9 times-from 2,593 to $5,044 .^{49}$

49. Census of Manufacture, 1966, 1972, 1976; Census of Commerce, 1966, 1976. 
Not all these firms were small businesses, however. The largest company among the newcomers, Renown, was established in Osaka by Yasohachi Sasaki, a wholesaler who had dealt in imported products such as perfume, blankets, and ties since 1902. He then started to manufacture knitwear products in 1926 and sold them to department stores. During World War II, Renown sewed military clothes, experimenting with methods of mass production. After the war, it sold knitted vests and jumpers and expanded to ready-to-wear jackets and suits from 1957 onward. It experienced rapid growth in the 1970s, a decade during which Renown actively launched items in the menswear category, using the French actor Alain Delon as a model in advertising. ${ }^{50}$

A second firm, Kashiyama, originated in 1927 in Osaka. The founder was Junzo Kashiyama, who was then a clerk at Mitsukoshi department store. Kashiyama also focused on wholesale. He imported perfume and sporting goods and produced sportswear before World War II, later launching his own ready-to-wear brands for menswear during the postwar recovery years. The company got American clothing from GIs (U.S. soldiers) and used reverse engineering to learn how to sew Western clothes. Kashiyama then sold its goods at department stores in the 1960s. ${ }^{51}$

Another company, Sanyo Shokai, was established by Nobuyuki Yoshihara in 1942 in Tokyo as a manufacturing and wholesaling company for textiles and other industrial goods. In 1945, its business transformed into the wholesale production of raincoats for department stores. Through radio advertisements and a marketing strategy that tied up with films, Sanyo Shokai expanded its merchandise lineup to include coats and suits. The firm obtained a license to manufacture Burberry coats in Japan and started selling them in 1965 and, a few years later, it expanded their licensed products to not only Burberry goods but also other well-known brands' products. ${ }^{52}$

These three companies found their market for clothing through department stores, which had all the latest fashions at the time-a partnership that helped the companies increase their sales. For example, sales to department stores accounted for 70 percent of Renown's total sales in $1955 .{ }^{53}$ Fast-growing demand among department store customers fueled further increases, with ready-to-wear garments becoming common among every generation and income group during the 1970s. As shown in table 1, Renown's sales in 1970 amounted to 36,131 million yen and increased to 205,808 million yen in 1980 (5.7 times over ten

50. Yamazaki, Renaun no keiei.

51. Kashiyama, Kashiyama Junzo, 39-76.

52. Sanyo Shokai, Sanyo DNA.

53. Kinoshita, Apareru Sangyo no Marketing shi, 110. 
Table 1 Sales of the largest clothing companies, in millions of yen, 1965-1985

\begin{tabular}{llllll}
\hline Company & 1965 & 1970 & 1975 & 1980 & 1985 \\
\hline Renown & 16,202 & 36,131 & 128,231 & 205,808 & 220,167 \\
Kashiyama & 8,513 & 27,815 & 81,778 & 150,430 & 175,954 \\
Sanyo Shokai & 3,900 & 12,072 & 28,018 & 58,067 & 89,236 \\
\hline
\end{tabular}

Source: Annual Securities Report, Renown, 1965, 1970, 1975, 1980, 1985; Annual Securities Report, Kashiyama, 1965, 1970, 1975, 1980, 1985; Annual Securities Report, Sanyo Shokai, 1965, 1970, 1975, 1980, 1985.

years); Kashiyama's sales in 1970 totaled 27,815 million yen and increased to 150,430 million yen in 1980 (5.4 times); and Sanyo Shokai's sales in 1970 came to 12,072 million yen, increasing to 58,067 million yen in 1980 (4.8 times). These new companies tapped the new market for ready-to-wear offerings along with department stores in Japan.

\section{The Major Role of Department Stores}

Department stores played a major role historically in the introduction of foreign luxury goods in Japan. Since the interwar years, they embodied modernity in new urban societies and offered a new form of material civilization to Japanese upper middle classes. In the 1950s and 1960s, they became important partners of French couturiers in bringing fashion to the Japanese market. ${ }^{54}$ However, department stores were not only leading fashion retailers with a stronger focus on the higher-end market than other retailers but also big sales outlets for apparel manufacturers and wholesalers. In 1977, for example, they sold 29.4 percent of all the women's clothing in Japan and 32.8 percent of children's clothing; specialty stores accounted for 45.8 percent and 24.0 percent, respectively. ${ }^{55}$ Department stores played a key role in the development of the apparel industry, particularly in three directions.

First, they transferred technology and skills related to the manufacturing of Western-style clothing to Japan. Japanese department stores also learned new methods for merchandising and producing ready-to-wear clothing from Western department stores in the 1950s. Representatives from Isetan, for example, visited Western department stores in 1951 and brought modern merchandise methods in the United States, along with the buyers' manual of the National Retail Merchants Association, into Japanese stores. ${ }^{56}$ Managers of other companies also visited Western department stores to understand their merchandise and copy their product displays. Back in Japan, they cooperated with apparel makers and launched new ready-to-wear clothing in the late 1950s.

54. Fujioka, "The Pressures of Globalization in Retail."

55. Kokumin Kinyu Kouko, Nihon no Fashion Sangyo, 218.

56. Isetan, 100 nenshi, 116-119. 
Second, Japanese department stores, as the leading retailers at the time, contributed to the standardization of ready-to-wear clothing. At first, there was some confusion over different standards of small, medium, and large sizes of clothing among manufacturers and retailers, as they each adopted their own standards. ${ }^{57}$ To avoid confusing customers, Isetan and two other department stores unified their standards based on data regarding their customers' body sizes. These standards then spread to all other department stores and manufacturers as fixed Japanese clothing sizes.

Third, they stimulated customer demand for Western-style clothing with their marketing strategies and expanded the market. Mitsukoshi started holding Western-style fashion shows in 1950, and Takashimaya held a catwalk fashion show with its licensed Pierre Cardin prêt-à-porter products in $1960 .{ }^{58}$ Because department stores attracted wealthy and fashion-conscious customers, they were the perfect places to introduce the latest Western fashion, including luxury fashion in the 1980s. ${ }^{59}$ As a result of these initiatives, ready-to-wear clothing became suitable for mass production and mass sales, and its market expanded.

Once the sales of ready-to-wear items increased and led to the mass production of Western garments, department stores reorganized the classifications of their sales areas from product categories to brand concepts. At the time, stores divided their sales areas according to product category, with separate sections for skirts, shirts, trousers, and so on; each category contained a mix of products from several different manufacturers. Then, clothing manufacturers presented their own concepts for different kinds of clothing. For example, a particular shirt and pair of trousers were coordinated in line with the new concept of "urban casual." Manufacturers thus adopted a certain image for presenting their products and were keen to foster customers who were loyal to their brand. ${ }^{60}$

Moreover, partnerships between department stores and apparel companies led to the introduction of new types of store operations. Clothing manufacturers requested two major changes. First, they introduced new transaction systems, such as consignment sales and concession sales. Kashiyama first introduced this new strategy in 1953. With consignment sales, department stores accepted more stock from clothing manufacturers, but they did so on a sale or return basis-a setup that greatly reduced the associated risk. With concession sales,

57. Ibid., 216-218.

58. Mitsukoshi, Mitsukoshi 100 nenno Kiroku, 173; Takashimaya, Takashimaya 150 nenshi, 151.

59. Fujioka, Li, and Kaneko, "The Democratization of Luxury."

60. Kinoshita, Apareru Sangyo no Marketing shi, 126. 
meanwhile, department stores offered portions of their sales floor to wholesalers and manufacturers and charged commissions according to their corresponding sales. As offers from clothing companies came in, department stores easily and rapidly expanded their merchandise and business without taking on the risk that came along with purchasing large quantities of stock. Clothing companies, too, rapidly increased their sales at the department stores. ${ }^{61}$

Second, clothing manufacturers provided their own shop floor sales staff, on their own budget, for every department store branch. This alleviated the risk for department stores in terms of increased labor costs, which were necessary for managing the increased stock. Although apparel companies had to deal with the higher initial costs, they were then able to control their points of sale, get direct feedback from their customers, and collect valuable customer data that helped them to adapt their production operations. ${ }^{62}$ The arrangement consequently worked out very well for them, as it did for department stores. This was a successful relationship between department stores and clothing manufacturers that developed along with the growing readyto-wear clothing market between the 1950s and 1970s.

With the introduction of consignment and concession transactions, clothing companies built numerous product brands for different market segmentations and expanded their sales areas within department stores in the 1970s. ${ }^{63}$ If a given clothing company had stuck with a single product brand, it would not have been able to expand its sales space at department store locations. However, by introducing a diverse mix of brands at a single store, it took much longer for a specific brand to reach a saturation point; this also meant that the company could construct a portfolio strategy. Renown, for example, provided its products through a single brand-“Renown"-in the 1960s but launched new brands one after another in the 1970s (e.g., Arnold Parmer, Koret, Adenda, and Simple Life), with consignment agreements for their own sales areas. ${ }^{64}$ The apparel company World, founded in 1959, had only four total brands in the 1960s; it then proceeded to launch twenty new brands in the 1970s and sixty-nine others during the 1980s. ${ }^{65}$ With that kind of variety, customers grew fond of particular brand names rather than company names, and department stores were easily able to expand brand lines and increase their own sales. Sales for clothing

61. Kashimaya, Kashiyama Junzo, 70-79.

62. Ibid., 71-72.

63. Kokumin Kinyu Kouko, Nihon no Fashion Sangyo, 102-123.

64. Kinoshita, Apareru Sangyo no Marketing shi, 126-131.

65. World 50th Anniversary Book, 329. 


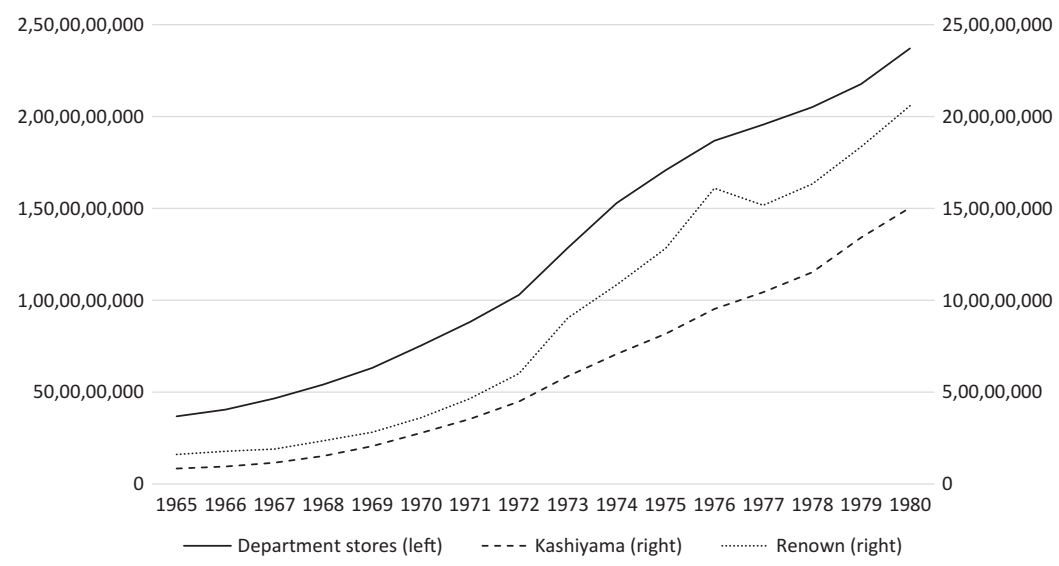

Figure 4 Total apparel sales of Japanese department stores and gross sales of Kashiyama and Renown, thousands of yen, 1965-1980.

Source: JDSA, Annual report of Japan Department Stores Association, 1981 and Annual Securities Report, Kashimaya and Renown, each year.

manufacturers therefore increased further as a result of their multibrand strategy for department stores.

Consequently, the emergence and development of a Western clothing industry in Japan had roots in a particular relationship between apparel companies and department stores. Figure 4 shows that the total apparel sales by all department stores in Japan followed a similar growth trend to that of the gross sales at leading apparel companies Kashiyama and Renown. These two actors contributed significantly to the creation of fashion as a cultural good in Japan. They were not alone, however. The next section will discuss the position of other actors, particularly designers and fashion media, and their connections with apparel companies and department stores.

\section{Emergence of New Intermediaries}

While apparel companies and department stores cooperated to produce Western clothing, a broad range of new actors emerged and played a major role in the construction of a fashion system in Japan. Designers, media, and various trade associations developed interconnected actions and thereby contributed to the production of Japanese fashion.

\section{Fashion Schools}

In the 1970s, Japanese designers began enjoying worldwide renown for their creativity and talent. Kawamura demonstrated that these 
designers, most of them trained in Tokyo, became famous outside of their home country by participating in fashion shows in Paris and New York, some earning acceptance as "haute couture" in Paris (e.g., Kenzo Takada). ${ }^{66}$ The fame that they gained abroad enabled them to establish themselves as respected fashion designers in Paris. Whereas scholars have detailed that process of career-making in previous studies, one must still discuss the impact of designers in the formation of a fashion system in Japan.

Designer schools played a major role as organizations that implemented and coordinated actions to connect designers with other actors in the fashion system. The Bunka Fashion College (Bunka Fukuso Gakuin, BFC), reopened in Tokyo in 1946, was the leading establishment for the diffusion of clothing knowledge and the training of designers. The institution's roots go back to a small, in-store workshop at a clothing store. The workshop began training young women to make Western garments using sewing machines in 1919. It had close ties to the manufacturer Singer and established itself as a first mover in creating Western fashion in Japan during the interwar years, launching the country's first fashion magazine-Soen-in 1936. Its objective was to promote the use and self-manufacture of Western clothing among the masses. ${ }^{67}$ After World War II, the reopened BFC grew quickly as the Westernization of fashion took off. Many young women and housewives entered schools like BFC, aiming to learn how to produce clothes. In 1960, 75.5 percent of all households in Japan already had sewing machines. ${ }^{68}$ However, people needed practical knowledge about how to use them properly; schools provided that vital instruction.

At the same time, BFC extended its activities from clothing to fashion. Since the early 1950s, for example, it organized fashion shows in Tokyo and other major cities like Nagoya, Osaka, and Kyoto. The college also engaged actively in fashion media. It relaunched Soen in 1946 and founded many of the first new fashion magazines in postwar Japan for a more segmented market, particularly High Fashion for wealthy people (1960) and Mrs. for young housewives (1961). Furthermore, BFC invited famous Western designers-like Christian Dior (1953), Howard Greer (1954), and Pierre Cardin (1958) — to give lectures and organize fashion shows. Another way the institution encouraged fashion in Japan was via the creation of several prizes for commendable design, including the Soen Prize (1957) and the Cardin High Fashion Prize, which occurred when Pierre Cardin was appointed emeritus professor

66. Kawamura, "The Japanese Revolution in Paris Fashion."

67. Bunka fukuso gakuin.

68. Gordon, Fabricating Consumers, 230-231. 
12000

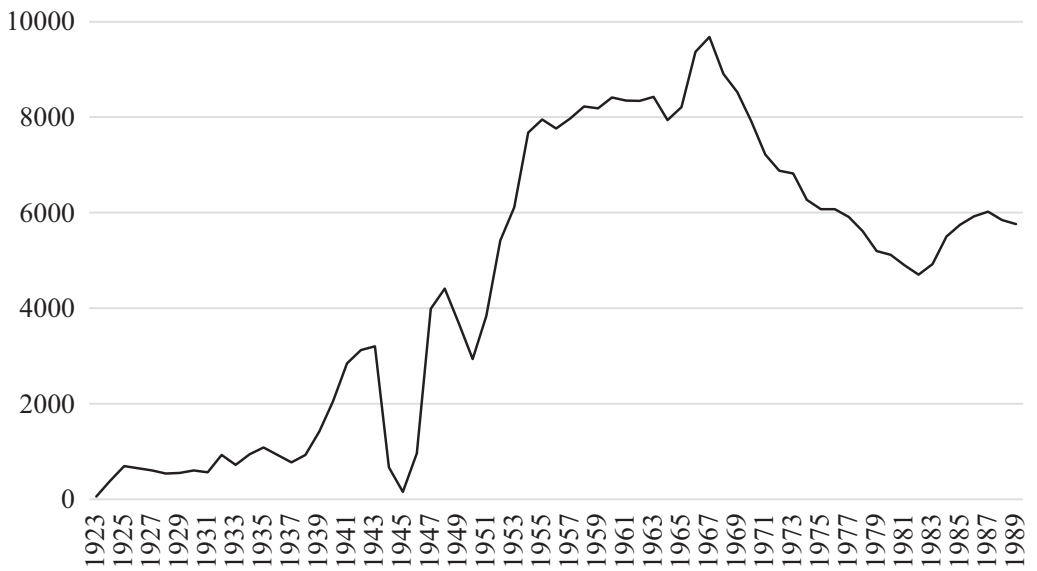

Figure 5 Number of students at Bunka Fashion College, 1923-1989.

Source: Bunka fukuso gakuin kyoiku shi, Tokyo: Bunka fukuso gakuin, 1989, p. 22.

of the school (1961). Finally, one must mention the setup of a division to train fashion models in 1953.

Consequently, the activities of BFC went far beyond the mere training of housewives and designers. It contributed greatly to the promotion of fashion and the construction of a fashion system in Japan during its formative years. BFC was not only involved in producing designers but also in broadening new styles of Western fashion, a process in which its students were instrumental. Figure 5 shows a rapid increase in the number of BFC students during the 1950s. BFC trained thousands of young girls (and boys from 1957 onward) in the various aspects of fashion. The number of students grew along with the demand for Western clothing. Once ready-to-wear fashion became popular, however, the number of students at BFC decreased in the 1970s, and the school refocused on designers.

Among other schools, Dressmaker Gakuin followed a model similar to BFC. Founded in Tokyo in 1926 by Yoshiko Sugino, a fashion stylist and businesswoman, it introduced the idea of ready-made clothes for women, based on standardized sizes, during the interwar years. ${ }^{69}$ Sugino and her students sewed and remade clothes for GIs during the postwar years, providing the learners with good opportunities to study Western clothing patterns, materials such as buttons and textiles, and stylebooks, as well as to foster continued growth into the future. The

69. Sugino, Shigaku keiei ni ikiru. 
school reopened in 1946 and expanded into about seven hundred affiliated schools to teach sewing skills and provide instruction on dress patterns. ${ }^{70}$ Later, Sugino also founded a publishing company, Kamakura Shobo, which launched fashion magazines like Dressmaking (1949) and Madam (1967), offering dress patterns that housewives could use for home sewing. In this way, Dressmaker Gakuin contributed to the spread of Western-clothing sewing in Japan, but it focused on tailor-made clothing in the higher-end market rather than ready-towear items, which became popular in the 1960s. ${ }^{71}$ Another institution meriting mention is Kuwasawa Design School (Kuwasawa dezain kenkyujo), which fashion and design journalist Yoko Kuwasawa opened in Tokyo in $1954 .^{72}$ The size of its organization and scope of its engagement in the fashion system were far below those of BFC and Dressmaker Gakuin, however.

Moreover, the actions of designers in promoting a fashion system went beyond the school channel. Designers themselves set up organizations to advertise their work collectively. Several groups were founded in Tokyo. The first was the Nippon Designers Club (NDC), organized in 1948 by Shiro Kimura, the boss at Stock Shokai, a Western fashion shop in Ginza. ${ }^{73}$ NDC gathered independent designers, artists, and people from schools. It organized fashion shows, the first one in 1949 in Tokyo, and the first professional fashion show in $1951 .{ }^{74} \mathrm{How}-$ ever, people from apparel companies and businesses organized a competing group, the Japanese Designers Association (Nihon dezaina bunka kyokai, NDK), in $1954 .{ }^{75}$ Design was considered a resource for the clothing industry, not an artistic activity. Therefore, the apparel industry wanted to exert control over designers. The first council of NDK was presided over by Bunzaburo Banno, a businessman active in trade with France.

However, independent designers, led by a few who had experienced success abroad (mostly in France), organized new groups to promote their creations through fashion shows. These groups were loosely structured and changed over time. One of the first was the Tokyo Collection Group (1964). ${ }^{76}$ Ten years later, six designers in the ready-to-wear business formed the TD6 (Top Designer 6) group to present their

70. Yoshimoto, "Hana Hiraku Yosai Gakkou”, 35-36.

71. Ibid., 36.

72. Tsunemi, Kuwasawa Yoko.

73. Council of Fashion Designers, Tokyo fasshon dezaina, 5.

74. Ibid., 6, 19.

75. Ibid., 24.

76. These designers were Hanae Mori, Harue Matsuda, Nabuo Nakamura, Masao Mizuno, Ku Hosono, Hiroko Nakajima, Mitsuko Morooka, and Hiroko Suzuki. Council of Fashion Designers, Tokyo fasshon dezaina, 49. 
collections in a joint arrangement twice a year. ${ }^{77}$ This event became Tokyo Fashion Week, whose first edition came in 1975. The success of the event attracted new designers and led to the founding of the Tokyo Collection Office (1981) and the Council of Fashion Designers (1985), which oversee Tokyo Fashion Week. The participation of star designers like Issey Miyake, Kansai Yamamoto, and Hiroko Koshino transformed this biannual show into a major event for the fashion business. These designers also sold their products to department stores, which is where fashion-conscious customers bought the latest clothing.

\section{Fashion Media}

Next, the fashion media industry established itself as a major actor in the Japanese fashion system. ${ }^{78}$ As we noted above, there were already a few magazines that existed during the interwar years and relaunched after the war. These magazines focused on the promotion of Western clothing toward housewives. During the 1950s, a new generation of media appeared with a new objective: contributing to the creation of fashion as a cultural value. About ten new magazines appeared in the years leading up to 1975. Designer schools, again, were among the first organizations to publish such magazines.

Publishing companies also engaged in this growing market after the war, Fujingaho being the largest of them. The firm, whose roots go back to the early twentieth century, launched Men's Club (1955). Other general publishers include Magazine House, with An-an (1970) and Popeye (1976), and Shueisha, with Seventeen (1968) and Non-no (1971). Finally, in an exceptional case, the famous designer Hanae Mori launched her own magazine in 1975: Ryuko Tsushin. ${ }^{79}$

The actions of fashion media transcended publishing, too. In 1952, four businessmen from the media industry, namely Isao Imaida (editor of magazines published by BFC), Tatsuo Maido (director of Fujingaho), Tadanobu Seto (from Nihon Orimono Shuppansha, founder of Vogue Japan in 1954), and Eitaro Hasegawa (founding director of Kamakura Shobo), gathered and organized the Fashion Editors Club of Japan (FECJ). ${ }^{80}$ The organization, which still exists today, has promoted fashion since 1956 by giving awards to people responsible for contributions to the development of design in Japan. ${ }^{81}$ FECJ introduced a foreign prize in 1994 and gave a special award to Uniqlo in 2001. It represents a classic example of how the fashion media industry legitimizes designers and creators.

77. Ibid., 75-76.

78. Inoue, "Nihon ni okeru fasshon-shi."

79. Namba, "Fasshon zasshi ni miru karisuma."

80. Fasshon editazu kurabu, Fasshon editazu kurabu 30 nen.

81. Council of Fashion Designers, Tokyo fasshon dezaina, 20. 
After the 1970s, the rapid development of the fashion business in Japan attracted a growing number of publishers in the fashionmagazine market, with a strong trend toward segmentation. More than forty new titles hit bookshelves during the 1980s, and again more than fifty during the 1990s. ${ }^{82}$ The sheer number of titles evinced a highly segmented market with hundreds of brand launches by apparel companies. Besides mass production and the diffusion of images and values linked to fashion, this period also saw general newspapers engage in fashion. They started organizing their own fashion shows and awards in the 1980s, for instance. ${ }^{83}$ Asahi Shimbun was one of the first, holding a show in honor of Issey Miyake and Kenzo for its 110th anniversary in 1989. It also organized The Givenchy Show (1983), whereas Yomiuri Shimbun launched the Tokyo Pret-a-Porter Collection (1985) and Fuji Sankei Group the Dream Factory (1987). The Mainichi Shimbun, meanwhile, created the Mainichi Fashion Prize in $1983 .{ }^{84}$ All were important steps toward fashion for the masses.

\section{Trade Associations}

Finally, a broad range of trade associations were founded in the textile industry after World War II and officially supported by the government. ${ }^{85}$ Most did not engage in any activities beyond production and technological issues. Some of them, however, contributed to the emergence of a fashion system in postwar Japan. For example, the Japan Fashion Color Association (Nihon Ryukoshoku Kyokai, JAFCA), founded in 1953, joined its counterparts in France and Switzerland in forming the International Commission for Color (Intercolor) in 1963. The organization's various events and meetings had a major impact on fashion forecasting through connections among designers, apparel and textile producers, and retailers. ${ }^{86}$

Other examples include the opening of a Japanese branch in Tokyo by the International Wool Secretariat, an organization founded in 1937 by woolgrowers in the British Empire, in $1953^{87}$ and the creation of the Nippon Uniform Center (NUC) in $1962 .{ }^{88}$ The latter underlined the role of these sorts of associations in connecting actors in the fashion system. The NUC's objective is to enable cooperation among different kinds of actors to develop uniforms for schools, companies, and other

\footnotetext{
82. Namba, "Fasshon zasshi ni miru karisuma."

83. Council of Fashion Designers, Tokyo fasshon dezaina, 63.

84. Council of Fashion Designers, Tokyo fasshon dezaina.

85. Matsushima, Tsusho Sangyo Seisakushi (8).

86. Blaszczyk and Wubs, The Fashion Forecasters.

87. Council of Fashion Designers, Tokyo fasshon dezaina, 13.

88. Ibid., 48.
} 
organizations. The chair of the first committee was Wajiro Kon (an anthropologist and architect, as well as a specialist in clothing design), and members included Makoto Urabe (a fashion critic in media and the director of the first Nobuo Nakamura show in Paris), Nobuo Nakamura (a designer), Yasuo Inamura (a professor of chemistry at the Tokyo Institute of Technology and a specialist in colors), Yoshisuke Kasai (the vice president of the Japanese Red Cross Society), Chie Koike (a designer), Kunio Hayashi (an independent fashion critic), Mitsuko Morooka (a designer) and Ayako Totsuka (an employee of JTB, which promotes tourism in Japan).

In addition, the Japan Apparel Industry Council, which was formally established in 1982 (despite launching their activities in 1979), was founded by large apparel companies such as Renown, Sanyo Shokai, and Kashiyama. It merged with the Tokyo Women's Children's Clothing Industry Association, Tokyo Men's Apparel Industry Association, and Harajuku Apparel Conference and reorganized itself as the "Japan Apparel Fashion Industry Council" in 2001. This association has played a significant role in developing the apparel industry in Japan in terms of enhancing the technology level in the 1980s and 1990s and the lobbying activity since 1990 s. $^{89}$

There were also associations without structural links to the textile industry but that still supported the development of fashion business. That was the case for model agencies, in particular, which provided young models for fashion shows and magazines. Shiro Kimura, founder of NDC, founded one of the first agencies-the Tokyo Fashion Model Club (TFMC)—in 1952. ${ }^{90}$ The following year, Kinuko Ito, a twenty-oneyear-old model and Japan's representative at the Miss Universe contest that year, founded the Fashion Model Group along with several colleagues. ${ }^{91}$

\section{The Creation of New Fashion Outlets}

Cooperating with department stores to produce Western clothing was not enough for the apparel industry to strengthen its position in the fashion system. Some designers and apparel companies tapped new sales channels: large shopping complexes in urban areas and train terminals where there was a concentration of different specialty fashion boutiques and no anchor tenants.

89. JAFIC.org, accessed July 4, 2019, http://www.jafic.org/.

90. Council of Fashion Designers, Tokyo fasshon dezaina, 19.

91. Niwa, Fasshon moderu. 
The first one was established in 1969 by Parco, a company belonging to the department store Seibu, at Ikebukuro station in Tokyo. Parco housed 170 up-and-coming specialty fashion boutiques and advertised itself to young consumers as the best place to shop for the newest fashion trends, rather than promoting certain individual shops onsite. The tenants of these boutiques were designers or companies that used them in the short term, depending on the success of their goods. This was a new business model for selling garments, as department stores and shopping malls usually have fixed tenants for their shops. ${ }^{92}$ Following Ikebukuro Parco's success, Shibuya Parco was launched in 1973. Next, in 1976, the East Japan Railway Company opened the Lumine fashion center in the Shinjuku Station building. The urban developer Mori Building founded Harajuku La Foret in 1978, and Tokyu Railway created the new Shibuya 109 building in 1979. These new shopping complexes made the areas of Shibuya and Harajuku the most fashionable shopping districts of Tokyo and Japan as a whole. They attracted fashion-conscious consumers from across the country-as well as Western scholars in fashion studies.

Within these buildings, young designers were able to develop their businesses by launching their own shops. They followed a very flexible production system with only a few core pieces. For example, the designers at La Foret included Takeo Kikuchi and Yoshie Inaba for Bigi and Comme Ça Du Mode, Mitsuhiro Matsuda for Nicole, and Yukiko Hanai, Junko Koshino, and Isamu Kaneko for Pink House. By giving these young designers a space in its building, La Foret benefited from their energy and enthusiasm for crafting new fashion. As these designers did not have the funds to establish their own shops individually, the setting of a fashion complex was an ideal platform for producing and showcasing their work.

The new fashion media also supported their growth. For example, An-an and Non-no, two leading fashion magazines in the 1970s, filled their pages with a bounty of images, combining different brands of tops, skirts, and trousers to create new and unique styles. These magazines echoed the sentiments of young designers who were proud to be different from the mainstream clothing industry, bringing their fresh perspectives to the market as designer brands. In these young designers' shops, instead of using mannequins, sales assistants themselves wore the clothes they sold-a new type of marketing strategy at the time. In this way, fashion brands catering to consumers with distinctive fashion tastes developed in the late 1970s and early 1980s. ${ }^{93}$

These fashion complexes also impacted Tokyo's street fashion. Young people shopping in these new urban outlets influenced fashion

92. Kawashima, Tokyo Fashion Biru.

93. Ibid. 
boutiques through their purchases and tastes, rather than the opposite. In the 1960s and 1970s, street fashion in Tokyo was heavily influenced by American West Coast fashion, including jeans and suit-style outfits inspired by the fashions of Ivy League students. ${ }^{94}$ However, in the 1990s, the new street fashion mostly came from teenagers, especially high school girls. Although they had to wear school uniforms, which were essentially all the same, they created their own fashion statements by doing things like wearing long, white, baggy knee socks that they pushed down their shins like leg warmers. Young students were the driving forces behind the movements of "costume play (cosplay)," in which people wear the outfits of their favorite animation characters, and "Gothic Lolita," a style featuring Victorian dresses with pale skin and neat hair. ${ }^{95}$

Fashion shopping complexes mainly focused on progressive customers, and the boutiques' designers tended to be avant-garde. These designers moved their sales areas from shopping complexes into department stores to gain more customers, however, once the designers were able to stand on their own feet. In 1977, a total of 32 percent of the sales of all women's outfits in Japan were made through department stores, which were the largest outlets in the market, although supermarkets had the largest sales of skirts. ${ }^{96}$

Although department stores were the dominant outlet in clothing sales, one must note that the successes of fashion shopping complexes, especially those in Tokyo, attracted many newcomers. Some companies focused on the import of fashion goods from different brands from all over the world instead of hiring their own designers. For example, Beams established its first "select shop" in 1976. ${ }^{97}$ Ships followed suit in 1977, as did United Arrows, which opened its first store in Shibuya in $1990 .{ }^{98}$ These stores had less merchandise than established department stores, but their selections of products reflected their respective stores' unique concept, taste, and positioning. The success of this strategy enabled these retailers to grow rapidly throughout the 1990s and beyond. Consequently, Japanese clothing outlets have diversified considerably since the 1970 s.

\section{The Fashion Strategy of Apparel Companies}

Finally, one must also discuss the fashion strategies of apparel companies. Their cooperation with department stores enabled them to produce

94. Marx, Ametora.

95. Kawamura, "Japanese Teens."

96. Kokumin Kinyu Koko, Nihon no Fashion Sangyo, 95.

97. Yamaguchi, Beams no Kiseki.

98. United Arrows, UA no Shinnen. 
Western clothing-but their scope of action extended beyond the manufacture of clothes. They also contributed toward "producing” fashion. Although the companies have exhibited different individual fashion strategies and specificities, two main common features are evident.

First, most apparel companies internalized the design function. When major apparel companies such as Renown, Kashiyama, and Sanyo Shokai shifted from clothing wholesaling to apparel manufacturing, they trained their own designers by themselves to align with their new factory equipment. The design was one of the process flows for these companies, and designers were in charge of the process. They thus designed clothing just as designers at the automobile manufacturers and home electric companies did. ${ }^{99}$ Cooperation with star designers who gained fame in Europe and the United States was very weak; most of the designers in that category established freelance careers upon returning to Tokyo and opened their own small companies, which was the case for designers who opened their first outlets at shopping complexes, as noted above. ${ }^{100}$ One exception is the collaboration between the giant apparel company World and the designer Takeo Kikuchi. World began marketing Takeo Kikuchi-designed men's clothes in 1984 and has since opened Takeo Kikuchi stores throughout Japan. ${ }^{101}$ For most Japanese apparel companies, though, design is a business-not a creative activity. This approach led many young talented designers to leave apparel companies and pursue their careers independently. Examples include Nobuyuki Inoue, who left the lingerie maker Wacoal, Yutaka Hasegawa, a former employee of Itokin, and Kyoko Higa, who started her career at World. All of them went freelance after a few years at large apparel companies. ${ }^{102}$

Second, apparel companies are characterized by a management approach dominated by a technological paradigm. ${ }^{103}$ As design is not considered as a creative activity, the development of clothes follows a rationalized, science-based procedure. Product-development divisions at apparel companies are thus usually headed by engineers. The case of the Fashion Technology Group (FTG), founded in 1976 by two engineers from major producers of artificial fibers (Asahi Kasei and Teijin) and one engineer from the Osaka-based apparel wholesale company Chori, illustrates this paradigm. These three men organized the FTG in order to scientifically measure the future of fashion. They believed that

99. Ejiri, Hyakkaten Henpinsei, 232.

100. Kawamura, The Japanese Revolution in Paris Fashion; see also the biographies of designers in Bunka fukuso gakuin, 198-203.

101. World 50th Anniversary Book, 150-157.

102. Bunka fukuso gakuin, 198-203.

103. Donzé, "Fashion Prediction and the Transformation of the Japanese Textile Industry." 
mathematically processing a broad range of data on clothes (e.g., size, color, shape) and demographics (e.g., gender, age, income) would make it possible to design the right products. In 1980, the FTG included twelve members, mostly from companies in the upstream part of the clothing industry (five from artificial-fiber companies, two from weavers, and one from a dyer); there were only two members from apparel makers and two from fashion intermediaries (one fashion coordinator and one from the fashion media industry). ${ }^{104}$

Consequently, for Japanese apparel companies, "fashion” is related to production and technology. The design of clothes is not a creative process but rather a purely material activity. This focus on technology is related to their highly segmented brand strategies. Meticulous market surveys make it possible to establish and distinguish customer needs with exacting precision and meet those demands with specific products and brands. In that sense, "fashion" is not a cultural value but a mere material good, synonymous with a "garment." Several trade associations in the apparel industry call themselves "fashion associations" despite representing clothing manufacturers and distributors, like the Japan Fashion Apparel Industry Council.

Figure 6 illustrates the specificity of the Japanese fashion system, as compared with the Western fashion system introduced at the beginning of this article, and summarizes some of our findings. The role of the intermediaries in the fashion system (schools of design, associations, media, and fashion shows) is not to legitimize designers, brands, and enterprises in order to create fashion as a cultural value; rather, the intermediaries serve to support the transmission of technical knowledge concerning clothing. Hence, apparel companies and independent designers produce "clothes" rather than "fashion" in the Western sense.

As section 2 explained, the modern fashion system took root in Western Europe after World War II to enable the sustainability and increase the profitability of apparel companies. The cooperation between apparel companies and department stores aimed at facilitating profit growth for both partners and building efficient supply chains, not at creating fashion. In this sense, "fashion" is not only related to the idea of a permanent change of style but also to the birth of strong brands that emerge from the system. However, despite having a long tradition of fashion consciousness since the Edo period, Japanese consumers have mostly given attention to the material characteristics of clothes (color, form, and fabric). ${ }^{105}$ This feature persisted throughout the interwar and postwar years in the context of the Westernization of clothing and the birth of an apparel industry. Thus, whereas figure 1 shows the crucial role of designers among intermediaries

104. Kawasaki, Fasshon tekunoroji no hasso, 9.

105. Tamura, Fashon no shakai keizai shi. 


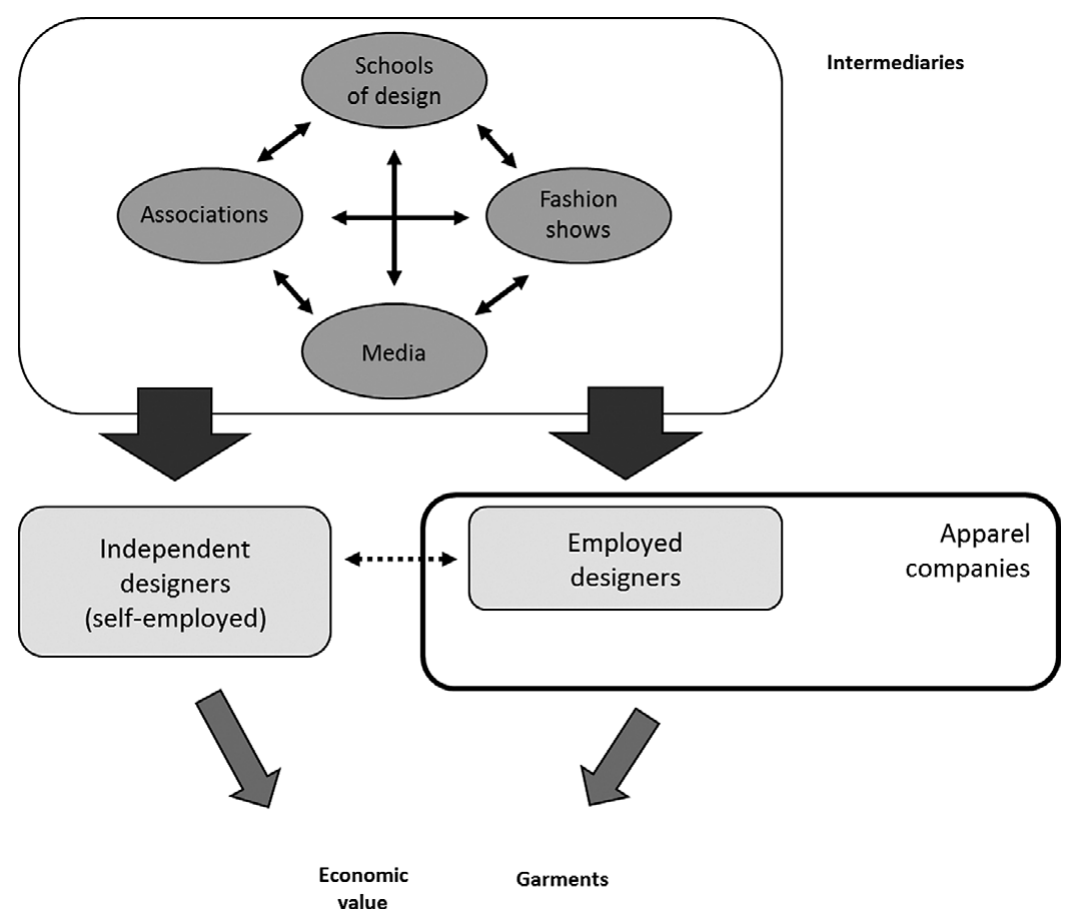

Figure 6 The Japanese fashion system.

Source: Drafted by the authors

and apparel companies in the Western setup, designers-whether independent or employed - work as people in charge of drawing the look and function in the Japanese system. They focus on creating garments and do not contribute significantly to building strong brands, unlike their Western counterparts. Consequently, brand management is considered an activity that must support the sales of all the various products manufactured for specific segments of the market, not a way to build a strong identity related to a broad range of goods, including accessories.

\section{Conclusion}

This article has demonstrated the emergence and formation of a Western clothing industry and fashion system in Japan between 1945 and 1990. By looking at a broad range of enterprises and actors, it has emphasized that the specificities of the Japanese fashion industry are far from the ethnic-based explanations that fashion scholars have traditionally offered. Street fashion and star designers in Paris are only anecdotal episodes, not full expressions of the industry's true nature. 
The Japanese fashion system must be understood first in the context of a cultural and industrial transplantation. Making Western clothes in Japan after World War II was a new activity that required new knowledge. Young women and housewives took classes at dressmaking schools and purchased fashion magazines to learn how to make Western clothes at home as well as acquire a sense of Western style. This process lasted the entire course of the 1950s and the 1960s. For enterprises, manufacturing and selling Western garments was also a challenge, which was very technological and industrial in nature at its beginning.

Since the 1970s, the growth of ready-to-wear production, driven by a new segment of apparel companies that mass-produced garments and distributed them through department stores and new sales outlets, led to the decline of handmade clothing by housewives. However, the productive and technological paradigm continued to dominate the apparel industry. Fashion was not (and still is not) considered a creative activity-it was a business based on complex and rational market analysis. The focus on the various needs and tastes of the population led apparel companies to adopt extreme segmentation strategies, making the Japanese apparel market home to a huge range of brands that, by extension, have a weak identity.

Consequently, the Japanese fashion system appeared and developed during the second part of the twentieth century on the basis of a technological and production paradigm. The interactions between the various enterprises and actors of the system had clear objectives: to enable the design, mass production, and consumption of Western clothes. Unlike fashion systems in France, Italy, or the United States, the goal was not to invest in creative activities in order to build strong brands and increase profits through ready-to-wear items and accessories. In Japan, apparel companies showed no interest in working on and codeveloping brands with star designers. Designers had to move to Paris or New York to boost their careers and usually ended up pursuing business back in Tokyo as independent small companies positioned in a niche market (creative fashion for wealthy people). Moreover, Japanese apparel companies did not-and could not-diversify toward cosmetics and accessories because of their different business models and the presence of entry barriers, which were profit-making divisions in Europe, due to their lack of fashion brands.

This difference in the nature of the fashion system explains the lack of strong fashion brands in Japan and the intrinsic weakness of the Japanese apparel industry in the global market. As long as the industry was domestically oriented in Japan, there was no problem-it still met customers' expectations. When powerful Western brands began entering the Japanese market in the 1990s and sagging consumption in Japan 
forced apparel companies to shift their attention toward the global market, however, the industry's inherent weaknesses led to a sharp drop-off in competitiveness among apparel companies. ${ }^{106}$ In addition, the relationship between apparel companies and department stores has suffered in light of deflationary conditions dating to the 1990s and the resulting shifts in the macroeconomic situation, considering that it was difficult for them to get away from familiar surroundings.

The fast fashion brand Uniqlo, which was not analyzed in this article as it developed after 1990, is both an exception to and expression of this specific fashion system. ${ }^{107}$ First, it is an exception, as it is the only Japanese brand able to compete in the global market of fast fashion. Its business model, based on the outsourcing of production, the building of a strong, single brand, and the extension of a monobrand store network through the mastering of IT technology, has put it in the same arena as world-class fast fashion brands such as H\&M, The Gap, and Zara. Uniqlo is an expression of the Japanese fashion system, too, in the sense that it focuses much more on productive and technological issues than on branding, styling, and storytelling. The cooperation with large Japanese chemical companies such as Toray led to the development of new kinds of fibers and highly functional materials. Uniqlo CEO Tadashi Yanai often says that "Uniqlo is not a fashion company; it's a technology company.”108

The Japanese fashion system thus did not change deeply in its structure since forming after World War II, resulting from a technologicaland production-based approach with roots going back to the end of the nineteenth century. ${ }^{109}$ Discussing how, why, and to what extent the initial conditions of fashion systems led them to evolve in a pathdependence approach (or not) goes beyond the scope of this article. This would, however, be a major topic for further research on fashion systems in both Japan and the West.

Consequently, this article offered a new interpretation of the Japanese apparel industry's decline since the mid-1990s and its inability to maintain a competitive edge. The use of the "fashion system" as an analytical tool and the business history approach shed light on the true nature of the Japanese apparel industry. Fashion studies has been a

106. Fujioka, "Sourcing Competition Across Industries."

107. The fist Uniqlo shop was opened in Hiroshima in 1984 by a wholesaler of clothes who wanted to have his own outlet. The company experienced an important growth in the domestic market since the late 1990s and in foreign markets since the twenty-first century. Choi, "The Rise of Uniqlo."

108. See for example Finningan, "The plain truth".

109. Choi, "The Genesis of Modern Management of Technology” and "UNIQLO and Tadashi Yanai." 
vibrant field in the social sciences for more than two decades, and business historians can contribute to renewing debates and reexamining issues. ${ }^{110}$

\section{Bibliography of Works Cited}

\section{Books}

Abe, Takeshi, and Kyohei Hirano. Seni Sangyo [Textile Industry]. Tokyo: Nihon Keieishi Kenkyusho, 2013.

Aoshima, Yaishi, Akira Takeishi, and Micahel A. Cusumano. Meido in japan ha owarunoka? [Is Made in Japan Over?]. Tokyo: Toyokeiyai, 2010.

Barthes, Roland. The Fashion System. New York: Vintage Books, 2010. [First French edition in 1967.]

Bartlett, Djurdja, Shaun Cole, and Agnès Rocamora, eds. Fashion Media: Past and Present. London: A \& C Black, 2013.

Blaszczyk, Regina Lee. The Color Revolution. Cambridge, MA: MIT Press, 2012.

- ed. Producing Fashion: Commerce, Culture, and Consumers. Philadelphia: University of Pennsylvania Press, 2008.

Blaszczyk, Regina Lee, and Véronique Pouillard, eds. European Fashion: The Creation of a Global Industry. Oxford: Oxford University Press, 2018.

Blaszczyk, Regina Lee, and Wubs Ben (eds.). The Fashion Forecasters: A Hidden History of Color and Trend Prediction. London: Bloomsbury, 2018.

Bouwens, Bram, Pierre-Yves Donzé, and Takafumi Kurosawa, eds. Industries and Global Competition: A History of Business Beyond Borders. New York: Routledge, 2017.

Ejiri, Hiroshi. Hyakkaten Henpinsei no Kenkyu [The Study on Return Institutional of Department Stores]. Tokyo: Chuo Keizaisha, 2003.

Francks, Penelope. The Japanese Consumer: An Alternative Economic History of Modern Japan. Cambridge: Cambridge University Press, 2009.

Fujimoto, Takahiro. Nihon no monozukuri tetsugaku [The Philosophy of Japanese Manufacturing]. Tokyo: Nihon keizai shimbun, 2004.

Godoy, Tiffany. Style Deficit Disorder: Harajuku Street Fashion-Tokyo. San Francisco, CA: Chronicle Books, 2007.

Gordon, Andrew. Fabricating Consumers: The Sewing Machine in Modern Japan. Berkeley: University of California Press, 2012.

Grumbach, Didier. History of International Fashion. Northampton: Interlink Books, 2014.

Itami, Hiroyuki. Nihon no sen'i sangyo: naze korehodo yowaku natte shimatta no ka [Japanese Textile Industry]. Tokyo: NTT, 2001.

110. See for example the pioneering works of Blaszczyk, Producing Fashion; Blaszczyk and Pouillard, European Fashion; Wubs and Maillet, "Building Competing Fashion Textile Fairs in Europe.” 
Ito, Motoshige. Hyakkaten no Mirai [The Future of Department Stores]. Tokyo: Nihon Keizai Shimbunsha, 1998.

Kawakami, Momoko, and Timothy J. Sturgeon, eds. The Dynamics of Local Learning in Global Value Chains: Experiences from East Asia. Basingstoke, UK: Palgrave Macmillan, 2011.

Kawamura, Yuniya. Fashioning Japanese Subcultures. London: Berg, 2013.

- Fashion-ology: An Introduction to Fashion Studies. London: Bloomsbury Publishing, 2005.

- The Japanese Revolution in Paris Fashion. Oxford: Berg, 2004.

Kawashima, Yoko. Tokyo Fashion Biru [Fashion Building in Tokyo]. Tokyo: Nihon Keizai Shimbun sha, 2007.

Kinoshita, Akihiro. Apareru Sangyo no Marketing shi [Marketing History of Apparel Industry]. Tokyo: Dobunkan, 2011.

Marx, David. Ametora: How Japan Saved American Style. New York: Basic Books, 2015.

Matsushima, Shigeru. Tsusho Sangyo Seisakushi (8): Seikatsu Snagyo Seisaku [History of Japan's Trade and Industry Policy (8): Consumer Goods Industries]. Tokyo: Keizai Sangyo Chosakai, 2012.

Meiji University. Za fasshon bijinesu [The Fashion Business]. Tokyo: Dobunka, 2015.

Niwa, Fumiya. Fasshon moderu [Fashion Models]. Tokyo: Kodansha, 1955.

Ohara, Yoko. Gurobarizeshon to dijitaru kakumei kara yomutoku [Globalization and Digital Revolution]. Tokyo: Senken, 2016.

Okonkwo, Uche. Luxury Fashion Branding: Trends, Tactics, Techniques. Basingstoke, UK: Palgrave Macmillan, 2007.

Omura, Kunitoshi. Fasshon bijinesu no shinka [Evolution of Fashion Business]. Osaka: Hannan University, 2017.

Ota, Yasuhiro. Seni Sangyo no Seisui to Sanchi Chusho Kigyo: Banshu Sakizome Orizomegyo niokeru Kyoso/Kyocho [Dynamics of Textile Industry and Its Small Medium-Sized Companies: Competition and Coordination among Yarn-Dyed Textile Industry in Banshu Area]. Tokyo: Nihon Keizai Hyoronsha, 2007.

Ozawa, Terutomo. The Rise of Asia: The "Flying-Geese" Theory and Tandem Growth and Regional Agglomeration. Cheltenham, UK: Edward Elgar, 2009.

Shioji, Hiromi. Higashi ajia yui sangyo no kyosoryoku: sono yoin to kyoso bungyo kozo [The Competitiveness of East Asian Industries]. Kyoto: Minerva, 2008.

Slade, Toby. Japanese Fashion: A Cultural History. London: Berg, 2009.

Steele, Valerie. Japanese Fashion Now. New York: Fashion Institute of Technology, 2010.

Sugihara, Junichi, and Mutsumi Somehara. Dare ga apareru wo korosu no ka? [Who Is Killing the Apparel Industry?]. Tokyo: Nikkei BP, 2017.

Tamura, Hitoshi. Fashion no shakai keizai shi: zairai orimonogyo no gijutsu kakushin to ryuko shijo [Socioeconomic History of Fashion: Technical Innovation of Conventional Textile Industry and Market Trends]. Tokyo: Nihon keizai hyoronsha, 2004.

Tsunemi, Mikiko. Kuwasawa Yoko to modan dezain undo [Kuwasawa Yoko and Modern Design]. Tokyo: Kuwasawa gakuen, 2007. 
Witt, Michael A., and Gordon Redding, eds. The Oxford Handbook of Asian Business Systems. Oxford: Oxford University Press, 2014.

Yamaguchi, Jun. Beams no Kiseki [Miracle of Beams]. Tokyo: Sekai Bunka sha, 2006.

Yamazaki, Katsunaga. Renaun no keiei [The Management of Renown]. Tokyo: President, 1978.

Yonekura, Seiichiro, and Hiroshi Shimizu. Open inobeshon no manejimento [Open Innovation Management]. Tokyo: Yuhikaku, 2015.

\section{Articles and Chapters in Books}

Azuma, Nobukazu. "Pronto Moda Tokyo-Style-Emergence of Collection-Free Street Fashion in Tokyo and the Seoul-Tokyo Fashion Connection." International Journal of Retail \& Distribution Management 30, no. 3 (2002): 137-144.

Bales, Carter F., P. C. Chatterjee, Fred W. Gluck, Donald Gogel, and Anupam Puri. "The Business System: A New Tool for Strategy Formulation and Cost Analysis.” McKinsey Quarterly June, (2000): 22-25.

Birtwistle, Grete, and Christopher M. Moore. "Fashion Clothing-Where Does It All End Up?" International Journal of Retail \& Distribution Management 35, no. 3 (2007): 210-216.

Brachet Champsaur, Florence. "Madeleine Vionnet and Galeries Lafayette: The Unlikely Marriage of a Parisian Couture House and a French Department Store, 1922-40.” Business History 54, no. 1 (2012): 48-66.

Cameron, Don. "Off-the-Rack Identities: Japanese Street Fashion Magazines and the Commodification of Style." Japanese Studies 20, no. 2 (2000): 179-187.

Choi, Eugene K. "UNIQLO and Tadashi Yanai." In Handbook of East Asian Entrepreneurship, by Fu-Lai Tony Yu and Ho-Don Yan, 240-251. New York: Routledge, 2014.

— . "The Genesis of Modern Management of Technology: The Case of the Meiji Cotton Spinning Sector in Globalization, 1880s-1890s." In Comparative Responses to Globalization, edited Maki Umemura and Rika Fujioka, 99-120. London: Palgrave Macmillan, 2013.

. "The Rise of Uniqlo: Leading Paradigm Change in Fashion Business and Distribution in Japan.” Entreprises et histoire 3, no. 64 (2011): 85-101.

Dion, Delphine. "Légitimité et légitimation des marques." In Management transversal de la marque, edited by Geraldine Michel, 31-44. Paris: Dunod, 2013.

Djelic, Marie-Laure, and Antti Ainamo. "The Coevolution of New Organizational Forms in the Fashion Industry: A Historical and Comparative Study of France, Italy, and the United States." Organization Science 10, no. 5 (1999): 622-637.

Donnelly, Tom, and David Morris. "Structural Change in the Chinese Car Industry." The Asia Pacific Journal of Economics \& Business 7, no. 1 (2003): 42-56.

Donzé, Pierre-Yves, and Ben Wubs. "Storytelling and the Making of a Global Luxury Fashion Brand: Christian Dior.” International Journal of Fashion Studies 6, no.1 (2019): 83-102.

Donzé Pierre-Yves, and David Borel. "Technological Innovation and Brand Management: The Japanese Watch Industry Since the 1990s." Journal of Asia-Pacific Business 20, no. 2 (2019): 1-20. 
Donzé, Pierre-Yves. "Fashion Prediction and the Transformation of the Japanese Textile Industry: The Role of Kentaro Kawasaki (1950-1990)." In The Fashion Forecasters: A Hidden History of Color and Trend Prediction, edited by Regina Lee Blaszczyk and Ben Wubs, 149-165. London: Bloomsbury, 2018.

Endo, Takahiro, Rick Delbridge, and Jonathan Morris. "Does Japan Still Matter? Past Tendencies and Future Opportunities in the Study of Japanese Firms." International Journal of Management Reviews 17, no. 1 (2015): 101-123.

Finningan, Kate. "The plain truth: Uniqlo boss Tadashi Yanai explains his plans for world domination.” The Telegraph, 12 March 2016.

Fontana, Giovanni Luigi, and José Antonio Miranda. "The Business of Fashion in the Nineteenth and Twentieth Centuries." Investigaciones de Historia Económica-Economic History Research 12, no. 2 (2016): 68-75.

Fujioka, Rika. "The Pressures of Globalization in Retail: The Path of Japanese Department Stores, 1930s-1980s." In Comparative Responses to Globalization, edited by Maki Umemura and Rika Fujioka, 181-203. London: Palgrave Macmillan, 2013.

_ . "Sourcing Competition Across Industries." In Industries and Global Competition: A History of Business Beyond Borders, edited by Bram Bouwens, PierreYves Donzé, and Takafumi Kurosawa, 175-193. Abingdon: Routledge, 2018.

Fujioka, Rika, Zhen Li, and Yuta Kaneko. "The Democratization of Luxury and the Expansion of the Japanese Market, 1960-2010.” In Global Luxury: Organizational Change and Emerging Markets since the 1970s, edited by Pierre-Yves Donzé and Rika Fujioka, 133-156. Singapore: Palgrave Macmillan, 2017.

Gilbert, David. "From Paris to Shanghai: The Changing Geographies of Fashion's World Cities." In Fashion's World Cities, edited by David Gilbert and Christopher Breward, 3-32. Oxford: Berg, 2006.

Gluck, Frederick W. "Strategic Choices and Research Allocation." The McKinsey Quarterly no. 1 (1980): 22-33.

Godart, Frédéric. "The Power Structure of the Fashion Industry: Fashion Capitals, Globalization and Creativity." International Journal of Fashion Studies 1, no. 1 (2014): 39-55.

Gustafsson, Robin, Mikko Jääskeläinen, Markku Maula, and Juha Uotila. "Emergence of Industries: A Review and Future Directions." International Journal of Management Reviews 18, no. 1 (2016): 28-50.

Inoue, Masato. "Nihon ni okeru fasshon-shi no seisei no rekishika" [Myth of the Origin of the Fashion Magazine in Japan]. Toshi bunka kenkyu 12 (2010): 125-138.

Jelinek, Julia-Sophie. "Art as Strategic Branding Tool for Luxury Fashion Brands." Journal of Product \& Brand Management 27, no. 3 (2018): 294-307.

Jiratanatiteenun, Aliyaapon, Chiyomi Mizutani, Saori Kitaguchi, Tetsuya Sato, and Kanji Kajiwara. "The Transformation of Japanese Street Fashion Between 2006 and 2011." Advances in Applied Sociology 2, no. 4 (2012): 292-302.

Kapferer, Jean-Noël. "Abundant Rarity: The Key to Luxury Growth.” Business Horizons 55, no. 5 (2012): 453-462.

Kawamura, Yuniya. "Japanese Teens as Producers of Street Fashion.” Current Sociology 54, no. 5 (2006): 784-801. 
"Placing Tokyo on the Fashion Map: From Catwalk to Street Style." In Fashion's World Cities, edited by David Gilbert and Christopher Breward, 55-68. Oxford: Berg, 2006.

Lundvall, Bengt-Åke. "National Business Systems and National Systems of Innovation." International Studies of Management \& Organization 29, no. 2 (1999): 60-77.

McCracken, Grant. "Culture and Consumption: A Theoretical Account of the Structure and Movement of the Cultural Meaning of Consumer Goods." Journal of Consumer Research 13, no. 1 (1986): 71-84.

— . "Who Is the Celebrity Endorser? Cultural Foundations of the Endorsement Process." Journal of Consumer Research 16, no. 3 (1989): 310-321.

McGray, Douglas. "Japan's Gross National Cool.” Foreign Policy 130, no. 130 (2002): 49-54.

Merlo, Elisabetta. "When Fashion Met Industry. Biki and Gruppo Finanziario Tessile (1957-72).” Journal of Modern Italian Studies 20, no. 1 (2015): 92-110.

Merlo, Elisabetta, and Francesca Polese. "Turning Fashion Into Business: The Emergence of Milan as an International Fashion Hub." Business History Review 80, no. 3 (2006): 415-447.

Mudambi, Ram, and Jonas Puck. "A Global Value Chain Analysis of the 'Regional Strategy' Perspective.” Journal of Management Studies 53, no. 6 (2016): 1076-1093.

Namba, Koji. “Fasshon zasshi ni miru karisuma.” Kansaigakuin daigaku shakai gakubu kiyo 87 (2000): 97-110.

Okawa, Tomoko. "Licensing Practices at Maison Christian Dior." In Producing Fashion: Commerce, Culture, and Consumers, edited by Regina Lee Blasczyk, 82-107. Philadelphia: University of Pennsylvania Press, 2008.

Otani, Tsuyoshi, KyoungOk Kim, Masato Takahashi, Sigeru Inui, Hideaki Morikawa, and Masayuki Takatera. "International Presence and Fashion Business in Japan.” Transactions of Japan Society of Kansei Engineering 13, no. 5 (2014): 629-668.

Paris, Ivan. "Fashion as a System: Changes in Demand as the Basis for the Establishment of the Italian Fashion System (1960-1970)." Enterprise \& Society 11, no. 3 (2010): 524-559.

Rabellotti, Roberta. "How Globalisation Affects Italian Industrial Districts: The Case of Brenta." In Local Enterprises in the Global Economy: Issues of Governance and Upgrading, edited by Hubert Schmitz, 140-173. Cheltenham, UK: Edward Elgar Publishing, 2004.

Sato, Yoshinobu, and Mark E. Parry. "Formation of the New Japanese Style Management Strategy." In Japanese Management in Change, edited by Norio Kambayashi, 65-84. Tokyo: Springer, 2015.

Segre Reinach, Simona. "China and Italy: Fast fashion versus prêt à porter. Towards a new culture of fashion." Fashion Theory 9.1 (2005): 43-56.

Shimokawa, Koichi. "Japan's keiretsu system: The case of the automobile industry." Japanese Economic Studies 13.4 (1985): 3-31.

Skov, Lise. "Dreams of small nations in a polycentric fashion world." Fashion Theory 15.2 (2011): 137-156.

Steele, Valerie. "Anti-fashion: the 1970s." Fashion Theory 1.3 (1997): 279-295. 
Storz, Cornelia. "Innovation, institutions and entrepreneurs: The case of 'cool Japan'.” Asia Pacific Business Review 14.3 (2008): 401-424.

Tanaka, Akira. "The Changing Business Models of Postwar Japan's Sōgō Shōsha." Japanese Research in Business History 30 (2013): 65-84.

Wei, YH Dennis, Jian Li, and Yuemin Ning. "Corporate networks, value chains, and spatial organization: A study of the computer industry in China." Urban Geography 31.8 (2010): 1118-1140.

Whitley, Richard. "Internationalization and varieties of capitalism: the limited effects of cross-national coordination of economic activities on the nature of business systems." Review of international political economy 5.3 (1998): 445-481.

Wubs, Ben, and Thierry Maillet. "Building Competing Fashion Textile Fairs in Europe, 1970-2010: Premiére Vision (Paris) vs. Interstoff (Frankfurt).” Journal of Macromarketing 37.1 (2017): 25-39.

Yoshimoto, Yoko. "Hana Hiraku Yosai Gakkou” [Developing Dressmaking School]. In Yosai no Jidai [The era of dressmaking], edited by Kazuko Koizumi, 21-46. Tokyo: OM Shuppan, 2004.

\section{Reports and Published Sources}

Apareru sapurai chen kenkyukai: hokokusho [Research Group on Apparel Supply Chain: Report]. Tokyo: Keizaisangyosho seizosangyokyoku, 2016.

Brand Finance. Apparel 50 2017: The Annual Report on the World's Most Valuable Apparel Brands. Brand Finance, 2017.

Bunka fukuso gakuin: 40 nen no ayumi [Bunka Fukuso Gakuin: 40th Anniversary]. Tokyo: Bunka fukuso gakuin, 1963.

Census of Commerce. Tokyo: Ministry of International Trade and Industry, 1960, 1966, 1970, 1972, 1976.

Census of Manufacture. Tokyo: Ministry of International Trade and Industry, 1966, 1972, 1976, 1980.

Council of Fashion Designers. Tokyo fasshon dezaina kyogikai 20 nen no ayumi to sengo nihon fasshon dezaina tanjoki [Tokyo Fashion Design Association: 20th Anniversary and the Birth of Japanese Designers After WWII]. Tokyo: Council of Fashion Designers, 1985.

Fasshon editazu kurabu. Fasshon editazu kurabu 30 nen no oi naru ayumi, 1952-1982 [Fashion Editors Club: 30th Anniversary]. Tokyo: Fasshon editazu kurabu, 1982.

Interbrand. "Best Japan Brands 2017," accessed January 12, 2018, http:// interbrand.com/newsroom/interbrand-japan-best-japan-brands-2017/.

Isetan. Isetan 100 nenshi [A 100-Year History of Isetan]. Tokyo: Isetan, 1990.

JAFIC.org, accessed July 4, 2019, http://www.jafic.org/.

Japan Department Stores Association. Nihon Hyakkaten Kyokai Tokei Nempo [Annual Report of Japan Department Stores Association]. Tokyo: Japan Department Stores Association, 2013.

Kashiyama, Junzo. Kashiyama Junzo: hashire onwado jigyo to keiba ni kaketa 50 nen, [Junzo Kashimaya]. Tokyo: Nihon Tosho Center, 1998. 
Kawasaki, Kentaro. Fasshon tekunoroji no hasso: ryuko yosoku kara shohin kikaku he [The Idea of Fashion Technology]. Tokyo: Daiamondo, 1981.

Kokumin Kinyu Kouko. Nihon no Fashion Sangyo [Japanese Fashion Industry]. Tokyo: Chusho Kigyo Risachi Senta, 1979.

Mitsukoshi. Mitsukoshi 100 nenno Kiroku [A 100-Year History of Mitsukoshi]. Tokyo: Mitsukoshi, 2005.

Sanyo Shokai. Sanyo DNA: Sanyo Shokai 60 nen shi [Sanyo Shokai 60-Year History]. Tokyo: Sanyo Shokai, 2004.

Sugino, Shigeichi. Shigaku keiei no ikiru: watashino seikatsu to kangae [The Management of Private School]. Tokyo: Nihon shobo, 1958.

Takashimaya. Takashimaya 150 nenshi [A 150-Year History of Takashimaya]. Osaka: Takashimaya, 1982.

United Arrows. UA no Shinnen [Faith of UA]. Tokyo: Nikkei Jigyo Shuppan Senta, 2014.

World. World 50th Anniversary Book (in Japanese). Kobe: World, 2009. 